\title{
Pengembangan bahan ajar mekatronika untuk program studi D3 Teknik Elektronika Fakultas Teknik Universitas Negeri Malang
}

\author{
Benny A. Prasetyo ${ }^{1}$, Dyah Lestari ${ }^{2}$, Siti Sendari ${ }^{3}$ \\ 1. Universitas Negeri Malang, Indonesia | prasetyobenny90@yahoo.co.id \\ 2. Universitas Negeri Malang, Indonesia | dyah.lestari.ft@um.ac.id \\ 3. Universitas Negeri Malang, Indonesia | siti.sendari.ft@um.ac.id
}

\begin{abstract}
Abstrak
Tujuan dari penelitian ini adalah untuk menghasilkan bahan ajar untuk Matakuliah Workshop Mekatronika. Bahan ajar yang dikembangkan berupa buku dan modul ajar yang materi pembelajarannya mencakup satu semester. Peneliti menggunakan model pengembangan milik Purwanto yang model pengembangannya diperuntukkan bagi pengembangan modul. Pengumpulan data validasi dan kelayakan dilakukan dengan menggunakan metode angket/kuesioner. Angket/kuesioner ditujukan bagi validator kegrafikan, validator materi, dan mahasiswa. Berdasarkan hasil analisis data dari hasil validasi dan uji coba dapat disimpulkan bahwa bahan ajar yang dikembangkan telah memenuhi kriteria sangat valid dan layak untuk dipergunakan dalam pembelajaran.
\end{abstract}

Kata kunci: pengembangan, bahan ajar, mekatronika 


\section{TEKNO Junal Teknologi Elektro dan Kejuruan}

http://journal2.um.ac.id/index.php/tekno | ISSN 1693-8739

\section{Pendahuluan}

Workshop mekatronika adalah ma-takuliah wajib bagi mahasiswa D3 Teknik Elektronika. Saat ini, bahan ajar yang diper-gunakan dalam kegiatan perkuliahan Workshop Mekatronika berupa buku referensi dan artikel yang bersumber dari internet. Teknik penyajian materi dilakukan dengan menggunakan presentasi Power Point yang berasal dari buku referensi dan artikel dari internet. Penyajian materi oleh dosen pengampu sudah sesuai dan mudah untuk dipahami oleh mahasiswa, selain itu mahasiswa juga dapat mengakses materi yang bersangkutan pada buku referensi yang telah tersedia di Perpustakaan Jurusan Teknik Elektro. Namun uraian materi yang disampaikan dianggap belum memenuhi kebutuhan mahasiswa yang ingin mengkaji lebih dalam mengenai materi perkuliahan Workshop Mekatronika.

Salah satu bahan ajar yang dapat membantu mahasiswa dalam memahami materi yang disajikan adalah modul dan buku ajar (Daryanto. 2013) (Ogata dan Katsuhiko, 2002). Modul dan buku ajar dianggap perlu untuk dikembangkan supaya maha-siswa dapat memahami materi yang sesuai dengan RPS (Rancang Perkuliahan Semes-ter). Pengembangan modul dan buku ajar diharapkan dapat memenuhi kebutuhan mahasiswa dalam mengkaji materi dari Matakuliah Workshop Mekatronika.

Rencana perkuliahan semester (RPS) Matakuliah Workshop Mekatronika memi-liki tujuh deskripsi kompetensi yang harus dikuasai oleh mahasiswa D3 Teknik Elektronika yaitu: 1) Memperjelas mekanik logam. 2) Memperjelas pengaturan putaran dengan roda gigi, rantai dan belt. 3) Melakukan pengaturan putaran dengan roda gigi, rantai dan belt. 4) Memperjelas dan mengendalikan arah dan putaran motor listrik DC (Servo, Steppermotor). 5) Melakukan pengendalian sistem dengan pneumatik. 6) Melakukan pengendalian sistem dengan hidrolik. 7) Melakukan pengendalian konveyor. Berdasarkan RPS Matakuliah Workshop Mekatronika, maka disusunlan bahan ajar yang berupa modul dan buku ajar yang sesuai dengan RPS.

Susunan buku ajar terbagi menjadi tiga bagian utama yaitu sistem mekanik, sistem elektrik, dan sistem kendali. Susunan buku ajar (outline) adalah sebagai berikut: 1) pengenalan mekatronika, 2) poros, 3) sabuk dan rantai, 4) roda gigi, 5) konveyor, 6) sensor, 7) motor, dan 8) sistem kendali. Sedangkan, modul ajar disusun berdasarkan buku ajar yang memiliki susunan sebagai berikut: 1) pengenalan mekatronika, 2) sistem mekanik, dan 3) sistem elektrik.

\section{Metode}

Model pengembangan dipergunakan untuk mengembangkan modul. Tahap pengembangan yang dimiliki oleh model ini adalah (1) tahap peren-canaan, (2) tahap penulisan, (3) tahap review, uji coba, dan revisi, dan (4) tahap finalisasi dan pencetakan. Setiap tahap pengembangan pada metode ini memiliki langkah dan tahapan yang menyesuaikan proses pengembangan modul (Purwanto, 2007). Pemilihan metode pengembangan ini dikarenakan metode yang dikembangkan dianggap sesuai dengan modul yang akan dikembangkan. Model pengembangan ini memiliki langkah pengembangan yang sederhana yang dapat mencakup keseluruhan langkah penelitian dan pengembangan secara terstruktur dan sistematis. 


\section{TEKNO Junal Teknologi Elektro dan Kejurvon}

http://journal2.um.ac.id/index.php/tekno | ISSN 1693-8739

Pelaksanaan penelitian dan pengembangan dengan menggunakan metode ini disesuaikan dengan kebutuhan penelitian. Peneliti juga mempertimbangkan aspek waktu penelitian yang dapat dikemas secara sederhana. Berikut adalah langkah pengembangan penelitian yang digunakan disajikan pada Gambar 1.

Tahap pertama pengembangan adalah tahap perencanaan yang dilakukan dengan menyusun Garis Besar Isi Modul (GBIM). Dalam penyusunan GBIM akan dilaksanakan observasi dan wawancara dengan dosen pengampu Matakuliah Workshop Mekatronika untuk mendapatkan gambaran serta masukan mengenai media yang selama ini dipergunakan. Setelah melakukan observasi, selanjutnya akan dilakukan pengkajian mengenai (1) sasaran dari modul yang disusun, (2) kompetensi atau tujuan yang ingin dicapai, dan (3) materi atau isi pelajaran yang akan disajikan.

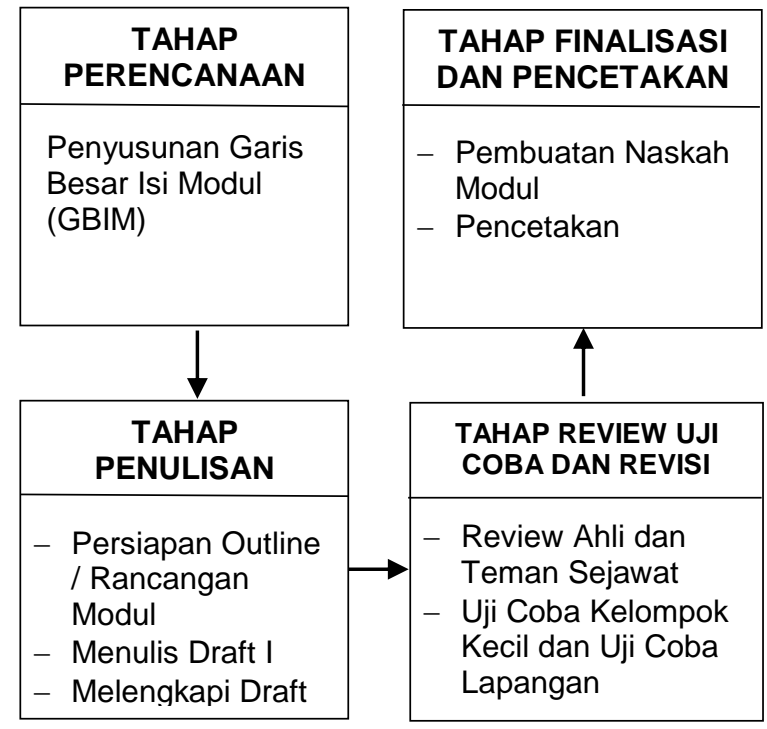

Gambar 1. Langkah-Langkah Pengembangan

Modul

Tahap kedua adalah tahap penulisan yang mencakup kegiatan perancangan outline modul, mempersiapkan draf pertama, dan perbaikan draf kedua yang merupakan perbaikan dari draf pertama. Perancangan outline adalah kegiatan untuk menentukan dan menyusun topik yang telah diketahui dari tahap pertama yang meru-pakan tahap penyusunan GBIM.

Tahap kedua adalah review, uji coba, dan revisi dan kegiatan pertama dalam tahap ketiga adalah melakukan review yang dilakukan dengan cara meminta pendapat dari validator materi dan validator kegrafikan, serta teman sejawat untuk membe-rikan masukan terhadap draf yang telah disusun. Tujuan dari dilakukan review adalah untuk memberikan masukan menge-nai 


\section{TEKNO Junal Teknologi Elektro dan Kejurvon}

http://journal2.um.ac.id/index.php/tekno | ISSN 1693-8739

materi yang berhubungan dengan isi modul dan teknik penyajian pada modul. Uji coba dilaksanakan dua kali yaitu uji coba terhadap kelompok kecil dan lapangan. Uji coba lapangan dilakukan jika pada uji coba kelompok kecil belum mendapatkan informasi yang dibutuhkan

Langkah yang keempat adalah tahap finalisasi dan pencetakan yaitu melakukan pemeriksaan terhadap tulisan, ilustrasi, dan penomoran, untuk selanjutnya modul siap untuk dicetak. Hal yang perlu untuk diperhatikan dalam pencetakan modul adalah mengenai tipografi, heading, penomoran halaman dan catatan kaki, layout, ilustrasi, dan penggunaan warna. Dengan memperhatikan beberapa hal tersebut, diharapkan hasil pencetakan dapat dibaca dan mudah untuk dipahami.

Sebagai dasar pengambilan keputusan untuk merevisi buku ajar yang dikembangkan, maka digunakan kriteria kualifikasi penilaian (Akbar, 2013). Kriteria penilaian yang dipergunakan memiliki 4 tingkat penilaian yaitu sangat valid (85,01\%-100,00\%); cukup valid (70,01\%-85,00\%); kurang valid (50,01\%-70,00\%); sangat tidak valid (00,00\%-50,00\%). Angket atau kuesioner yang dipergunakan dalam penelitian dan pengembangan ini. mempergunakan aspek penilaian (BSNP, 2014). Perhitungan data hasil yang diperoleh mempergunakan rumus atau persamaan sebagai berikut:

$$
\begin{array}{cc}
\text { V_(-ah) }=\text { TSe } / T S h \times 100 \% & \text { pers (1) } \\
\text { V_(-au) }=\text { TSe } / T S h \times 100 \% & \text { pers (2) }
\end{array}
$$

Keterangan :

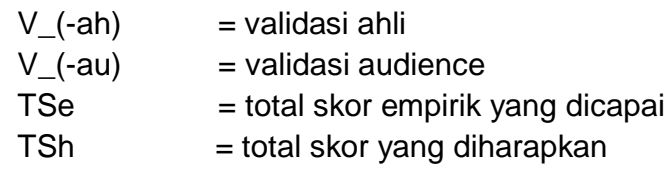

Setelah melakukan penganalisisan data angket yang mempergunakan persamaan 1 dan 2 maka, modul dan buku ajar yang dikembangkan akan dikatakan berhasil dan dapat dimanfaatkan sebagai bahan ajar apabila mencapai kriteria minimal cukup valid (validasi oleh validator) atau cukup layak (uji coba kelompok kecil dan lapangan) yaitu 70,01\% - 85,00\%.

\section{Hasil}

Produk yang dihasilkan dalam penelitian dan pengembangan ini adalah bahan ajar yang berupa modul dan buku ajar yang diperuntukkan bagi mahasiswa D3 Teknik Elektronika Universitas Negeri Malang untuk Matakuliah Workshp Mekatronika 


\section{TEKNO Jumal Teknologi Elekro dan Kejuruan}

http://journal2.um.ac.id/index.php/tekno | ISSN 1693-8739

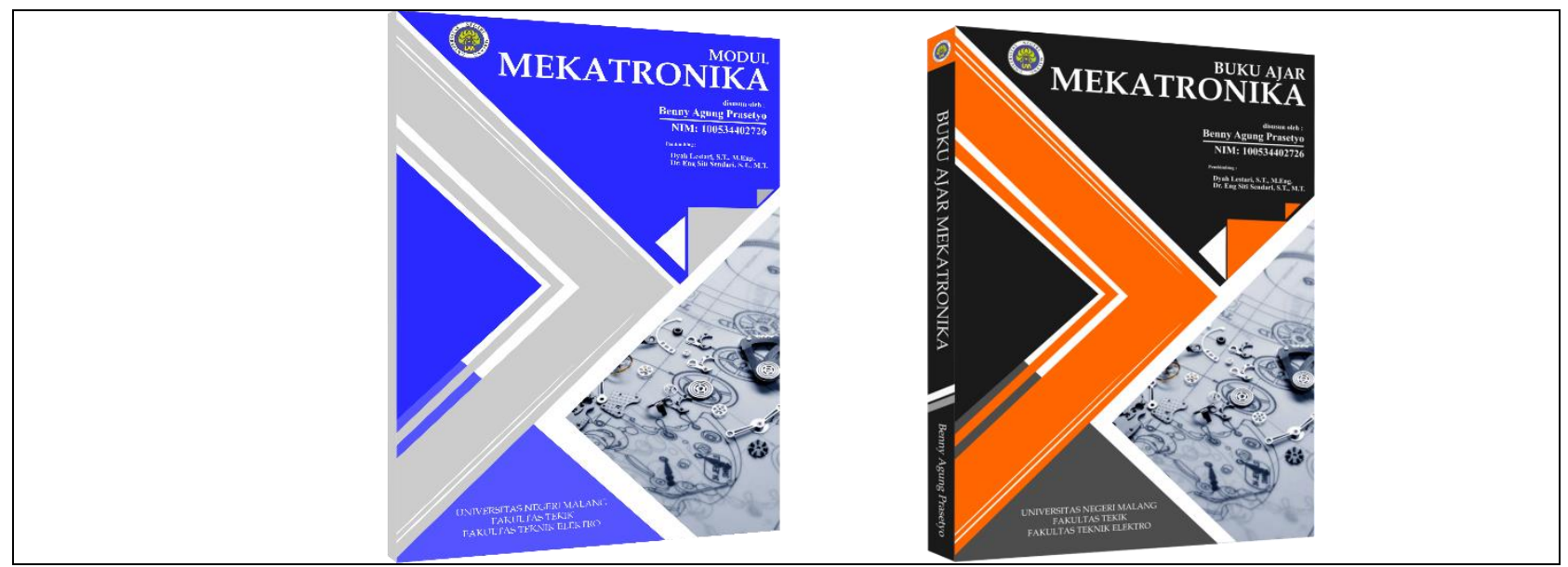

Gambar 2. Bahan Ajar yang Telah Dikembangkan Berupa Modul Dan Buku Ajar

Berdasarkan metode pengembangan, produk yang dihasilkan diujikan kepada tiga subjek uji coba yaitu validator kegrafikan, validator materi, dan mahasiswa. Terdapat beberapa aspek penilaian yang berbeda pada angket penilaian yang diberikan kepada ketiga subjek uji coba.

Aspek penilaian pada uji validasi kegrafikan meliputi: (1) desain kulit dan (2) desain isi, sedangkan validator materi memiliki tiga aspek penilaian yaitu: (1) kelayakan isi, (2) komponen penyajian, dan (3) komponen kebahasaan. Aspek penilaian pada uji kelayakan pada mahasiswa berupa: (1) desain kulit, (2) komponen penyajian, dan (3) komponen kebahasaan. Dari aspek penilaian diperoleh data yang menyatakan bahwa modul dan buku ajar memiliki tingkat kevalidan dan kelayakan yang cukup tinggi.

\section{Hasil Review}

Data hasil dari review diperoleh dari satu orang validator, dan beberapa teman sejawat. Dari hasil review diperoleh masu-kan yang berhubungan dengan penyajian modul maupun buku ajar mekatronika. Masukan yang diperoleh dari review diantaranya adalah: (1) perlu dijelaskan hubungan antara modul dan buku ajar, (2) perlu adanya perbaikan dalam tata tulis, dan (3) perlu menambahkan dan perbaikan kejelasan ilustrasi.

\section{Data Hasil Uji Coba Modul Ajar}

Hasil penilaian modul ajar pada uji validasi yang dilakukan oleh validator kegrafikan dan validator materi mengha-silkan data kuantitatif sebagai berikut: uji validasi kegrafikan oleh Dyah Lestari, S.T., M.Eng. memperoleh hasil penilaian pada (1) desain kulit modul sebesar 88,19\%, dan (2) desain isi modul sebesar 97,32\%; sedangkan pada uji validasi materi oleh Dr. Eng. Siti Sendari, S.T, M.T. memperoleh hasil penilaian pada (1) kelayakan isi sebesar 90,83\%, (2) komponen penyajian sebesar sebesar 90\%, dan (3) komponen kebahasaan 89,71\%.

Selain uji validasi penelitian dan pengembangan ini juga melakukan uji kelayakan pada mahasiswa D3 Teknik Elektronika 2014 dan S1 PTE 2010 yang berjumlah 10 orang 


\section{TEKNO Junal Teknologi Elektro dan Kejurvon}

http://journal2.um.ac.id/index.php/tekno | ISSN 1693-8739

memperolah hasil sebagai berikut: (1) desain kulit sebesar $87,14 \%$, (2) komponen penyajian sebesar $87,14 \%$, dan (3) komponen kebahasaan sebesar $87,5 \%$.

\section{Data Hasil Uji Coba Buku Ajar}

Hasil penilaian modul ajar pada uji validasi yang dilakukan oleh validator kegrafikan dan validator materi mengha-silkan data kuantitatif sebagai berikut: uji validasi kegrafikan oleh Dyah Lestari, S.T., M.Eng. memperoleh hasil penilaian pada (1) desain kulit modul sebesar 87,92\%, dan (2) desain isi modul sebesar 100\%; sedangkan pada uji validasi materi oleh Dr. Eng. Siti Sendari, S.T, M.T. memperoleh hasil penilaian pada (1) kelayakan isi sebesar 95\%, (2) komponen penyajian sebesar sebesar $91,56 \%$, dan (3) komponen kebahasaan $91,07 \%$.

Selain uji validasi penelitian dan pengembangan ini juga melakukan uji kelayakan pada mahasiswa D3 Teknik Elektronika 2014 dan S1 PTE 2010 yang berjumlah 10 orang memperoleh hasil sebagai berikut: (1) desain kulit sebesar 85,36\%, (2) komponen penyajian sebesar 87,14\%, dan (3) komponen kebahasaan sebesar 88,5\%.

Dari hasil uji coba yang dilakukan kepada subjek uji coba, modul ajar yang dihasilkan memperoleh data hasil seperti yang diperlihatkan pada Gambar 3.

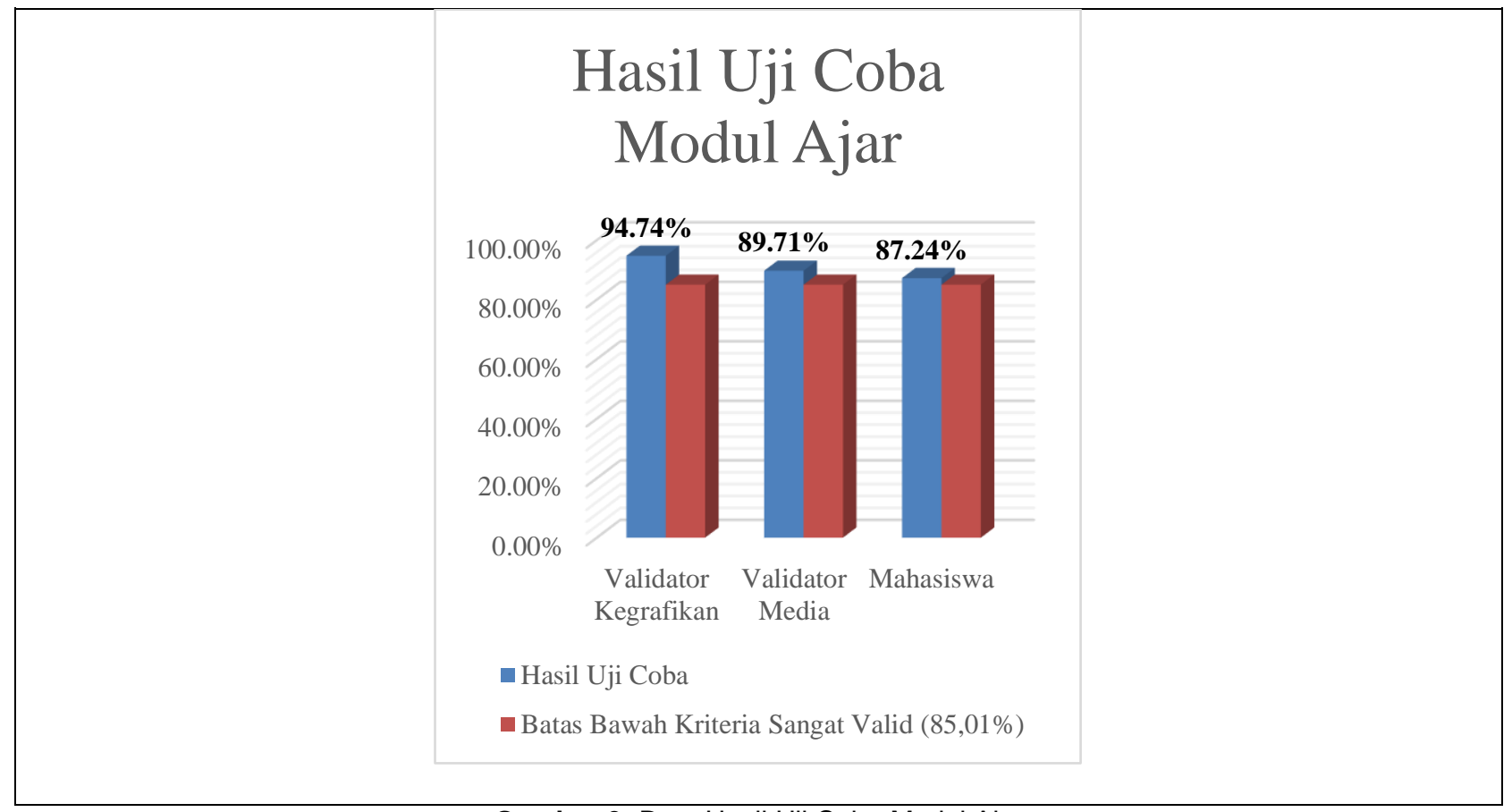

Gambar 3. Data Hasil Uji Coba Modul Ajar

Sedangkan buku ajar yang dihasilkan mem-peroleh data hasil seperti yang ditunjukkan pada Gambar 4. 


\section{TEKNO Junal Teknologi Elektro dan Kejuruan}

http://journal2.um.ac.id/index.php/tekno | ISSN 1693-8739

\section{Hail Uji Coba Buku Ajar}

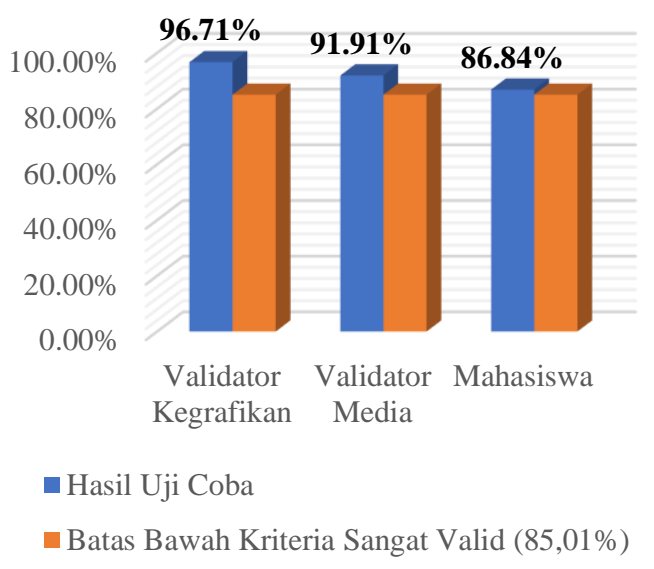

Gambar 4. Data Hasil Uji Coba Buku Ajar

Data hasil yang diperoleh dari uji coba kelompok kecil menunjukkan bahwa modul dan buku ajar yang dikembangkan memiliki hasil yang dapat dikategorikan sangat valid pada uji validasi dan sangat layak pada uji kelompok kecil. Hasil uji coba yang telah dilakukan memiliki beberapa poin peni-laian yang memerlukan perbaikan kecil sehingga modul dan buku ajar dapat dipergunakan. Perbaikan pada poin penilaian yang dianggap cukup valid dan cukup layak tetap dilaksanakan, meskipun poin peni-laian tersebut tidak mempengaruhi sub aspek penilaian secara signifikan.

\section{Kesimpulan}

Hasil dari review yang dilakukan oleh validator dan teman sejawat menunjukkan terdapat beberapa hal yang harus diperbaiki adalah mengenai tata tulis dan menam-bahkan serta memperbaiki ilustrasi yang kurang jelas. Setelah dilakukan revisi berdasarkan hasil dari review, maka hasil validasi dari modul dan buku ajar memiliki nilai rata-rata di atas $85,01 \%$ dan hasil tersebut termasuk dalam kriteria sangat valid. Hasil validasi oleh validator materi adalah $89,71 \%$ untuk modul ajar dan 91,91\% untuk buku ajar. Hasil validasi oleh validator kegrafikan adalah $94,74 \%$ untuk modul ajar dan 96,71\% untuk buku ajar. Setelah dilaksanakan uji coba kelompok kecil hasil dari kelayakan modul dan buku ajar adalah 87,24\% untuk modul ajar dan 86,84\% untuk buku ajar. Hasil yang diperoleh dari validasi serta uji coba kelompok kecil menunjukkan data yang diperoleh telah sesuai dengan kriteria yang diinginkan, serta modul dan buku ajar dapat dipergunakan bagi mahasiswa yang menempuh Matakuliah Workshop Meka-tronika bagi mahasiswa D3 Elektronika Universitas Negeri Malang. 


\section{TEKNO Jumal Teknologi Elekro dan Kejurvan}

http://journal2.um.ac.id/index.php/tekno | ISSN 1693-8739

Saran pemanfaatan modul dan buku ajar dalam proses pembelajaran adalah lebih memfokuskan proses pembelajaran pada sistem mekanik, karena sistem mekanik adalah hal baru bagi mahasiswa D3 Teknik Elektro. Sistem mekanik pada modul dan buku ajar memiliki bagian utama seperti poros, sabuk dan rantai, dan roda gigi. Saran bagi pengembangan produk lebih lanjut dapat dilakukan dengan menambahkan materi dan sumber yang dapat dijadikan rujukan pada modul dan buku ajar. Uji coba dapat dilakukan dengan sekala yang lebih besar dengan melakukan uji coba lapangan, untuk memperoleh data yang lebih realistik atau nyata jika data uji coba kelompok kecil dianggap belum memberikan informasi yang dibutuhkan. Diseminasi atau tahap penyebarluasan dapat dilakukan dengan memperhitungkan beberapa hal seperti cara mempelajari modul dan buku ajar, waktu yang diperlukan untuk mempelajari, dan teknik pengawasan atau pendampingan bagi pengguna. Hal tersebut dilakukan untuk mengetahui tingkat relevansi modul dan buku ajar yang dikembangkan, juga tingkat kecukupan materi yang terkandung dalam modul dan buku ajar.

\section{Daftar Rujukan}

Akbar, S. 2013. Instrumen Perangkat Pembelajaran. Bandung: PT. Remaja Rosdakarya. BSNP. 2014. Aspek Penilaian Terhadap Buku Ajar: Kelompok peminatan IPA dan Aspek Kegrafikan. Diakses pada 27 Maret 2016.

Daryanto. 2013. Menyusun Modul Bahan Ajar untuk Persiapan Guru dalam Mengajar. Yogyakarta. Gava Media.

Ogata, Katsuhiko. 2002. Modern Control Engineering. New Jersey: Prentice-Hall, Inc. Purwanto. dkk. 2007. Seri Teknologi Pembelajaran: Pengembangan Modul. Jakarta. Pusat

Teknologi Informasi dan Komunikasi Pendidikan (PUSTEKOM) Depdiknas. 